Vol. 7, No. 2, 2020

https://doi.org/10.23939/eem2020.02.016

UDC 657.01

JEL Classification Code: M41, L24

\author{
V. Hyk \\ Lviv Polytechnic National University, Ukraine, \\ Ph. D. in Economics, Associated Professor \\ e-mail: Vasyl.V.Hyk@lpnu.ua \\ ORCID ID: 0000-0002-3008-9216
}

\title{
CLUSTER AS AN OBJECT OF RESEARCH IN THE INSTITUTIONAL ECONOMY AND ACCOUNTING: SQUARE PLATES
}

\begin{abstract}
A critical analysis of globalization processes in the economy is considered and conducted, with an emphasis on the factors of increasing competition. It is established that due to the development of scientific and technological progress of new approaches to socioeconomic development requires the formulation of a new type of institutional environment. It is argued that an important tool for increasing the competitiveness of the economy are the processes of adaptive clustering. It is noted that in the Ukrainian national economy this approach has not become widespread and it is proved that an important component of inhibiting these processes is the lack of proper information base. It is proved that under such conditions an important role in information support belongs to the accounting system. The hypothesis of the study is the assumption that the creation of an accounting and information system in the management of cluster associations should be based on an institutional approach. From this conceptual approach, a study of the current state of accounting in the cluster, taking into account institutional theory. The purpose of the article is to clarify the disposition of accounting as a socio-economic institution and the formation of a cluster as a systemic institution. The existence of a slightly different nature of the interaction of these institutions is established, in which the role of the accounting information system is considered differently, in which it is considered in understanding the information network of the enterprise, and thus differs from the "traditional" interaction "accounting - enterprise". The study identifies the main reasons for the need to use the provisions of institutional theory to address the problems of accounting in the cluster. Based on the study, we propose to consider pre-grouping these concepts (institutional theory, accounting, cluster) and divide them into separate planes: the impact of institutional
\end{abstract}

theory on the development of accounting, cluster from the standpoint of institutional theory, institutional interaction between accounting and cluster.

Key words: accounting, institutional theory, information network of communications, integrated structures, cluster.

\section{Introduction}

Given the process of preparation of Ukraine for accession to the European Union, the issues of increasing the competitiveness of the national economy are becoming relevant. The Global Competitiveness Report 2019 [17], published by the World Economic Forum as part of the System Initiative for Shaping Future Economic Progress, provides a ranking of countries according to the Global Competitiveness Index. According to the study, Ukraine ranked 85th among 141 countries and deteriorated its position compared to the previous period by four positions.

One of the means of bringing the Ukrainian economy on an innovative path of development and overcoming disparities in the development of regions is the creation of research, innovation and production clusters. It should be noted that the cluster approach in Ukraine began to be introduced relatively recently and has not yet become widespread, due to the lack of appropriate regulations, clustering strategy of the national economy and the proper information base. Under such conditions, there is a need to form a system of accounting for the cluster, which would provide information to economic agents in particular and the state in general in the context of the economic globalization. 


\section{Cluster as an object of research in the institutional economy and accounting: square plates}

The analysis of research and problem statement

Problematic issues of accounting in the cluster are devoted to the works of Govda V. V., Degaltseva Zh. V., Osmonova A. A., Pilipenko A. A., Pronyaeva L. I., Fedotenkova O. A., YukhimenkoNazaruk I. A. etc. Accounting scientists mentioned above considered the general approaches to building an accounting system in integrated associations, while some institutional aspects in the cluster were ignored were not taken into consideration.

Based on this, we believe that the creation of an accounting and information system in the management of cluster associations should be carried out taking into account the institutional approach. "It is believed that this approach will allow to build a balance between theoretical concepts and practical constructions, which can be achieved by taking into account the role of economic institutions in the transformation of the accounting system" [14, p. 86]. "Institutional theory, allows to raise research to a high theoretical level through the use of scientific institutionalists on one side and allows to bring research in the field of accounting closer to the level of accounting practice on the other" $[15$, p. 36$]$.

The purpose of the article is to substantiate the role and importance of the institutional environment in the development of accounting in the cluster.

The methodological basis of the study is a set of fundamental provisions of institutionalism, scientific concepts of leading foreign and domestic experts in accounting. Methods of induction and deduction, analysis and synthesis, theoretical generalization and comparison are used in the study of theoretical aspects of institutional principles of accounting. Bibliographic and bibliometric analysis provided the identification of the most pressing issues of cluster research in institutional economics.

\section{Research results.}

We suggest hereby to consider the study of the current state of business accounting in the cluster, taking into account the institutional theory after grouping these concepts and dividing them into separate planes (Fig. 1).

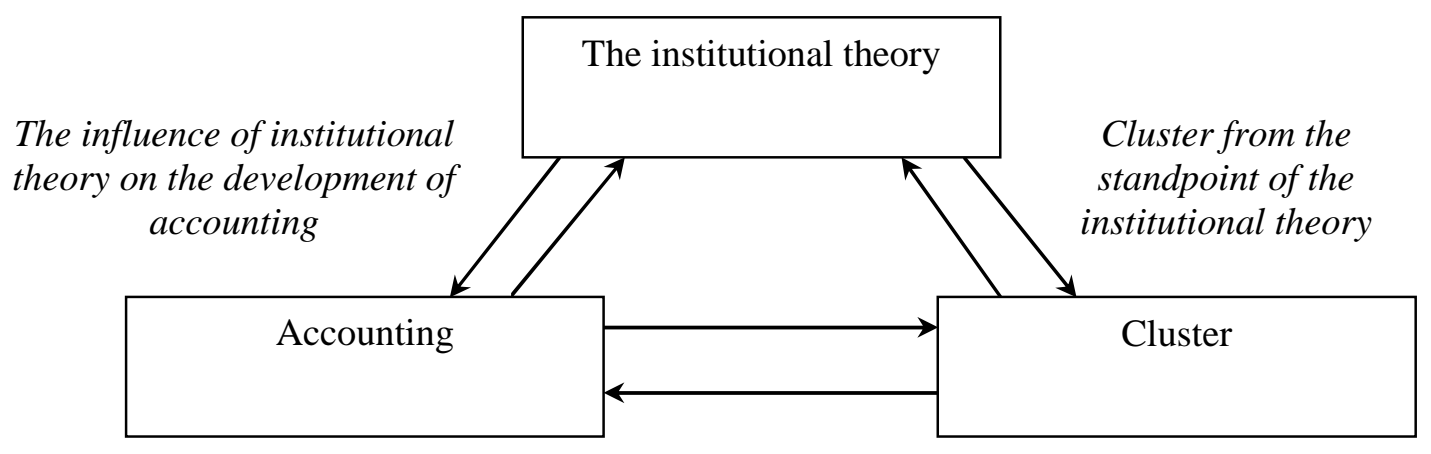

The institutional interaction between accounting and cluster

Fig. 1. Cluster as an object of study in institutional economics and accounting: planes of intersection

Source: developed by the author

1. The influence of institutional theory on the development of accounting. Ukrainian scientists as Vysochan O. S., Golov S. F., Zhuk V. M., Kantsurov O. O., Kireitsev G. G., Legenchuk S. F., Metelitsa V. M., Petruk O. M., Semenishena N. V., Sadovska I. B., Slozko T. M., Yaremko I. Y. etc. paid attention to the issue of considering the development of accounting through the application of the provisions of institutional theory. In recent years, there were defended doctoral theses in Ukraine by Kantsurov O. O. "Institutional principles of accounting development" (2015), Metelitsa V. M. "Development of the accounting profession in the agricultural sector of the economy: theory, methodology, practice" (2016), Sadovska I. B. "Development of theory, methodology and practice 
of management accounting: institutional-engineering aspects" (2018), which are devoted to the study of accounting on the basis of institutionalism, which indicates the relevance of its use in the context of globalization and transformation of the domestic economy.

The foundations of the domestic institutional theory of accounting were laid by V. M. Zhuk, who suggests that "the institute of accounting is a crucial component of the economy, formed both by informal institutions "in the minds" of accountants and users of accounting information, as well as by a formal feature of the "written rules of the game". This issue is implemented in specific organizations at the micro-, macro- and meso-levels, in order to understand and manage the socio-economic environment" [8, p. 17].

Petruk O. M. considers accounting as a social and economic institution that not only manages the activities of economic entities (enterprises, banks, investment funds) regardless of their nationality, but is also used by the state as an element of regulation and satisfaction of public interests [13, p. 144].

Kantsurov O. O. remarks that "Accounting is an integrated type of socio-economic activity and the only object of the knowledge that can be represented in research by the process of creation of economic information, information system, science and socio-economic institute [10, p. 360].

It should be emphasized that despite the numerous insights, the approaches to the basic provisions remain incomplete, and the statements about the recognition of accounting as a socioeconomic institution are debatable. The development of the institutional concept of accounting is at an early stage, but the conclusions obtained on its basis indicate the prospect of further solutions [18, p. 251].

Thus, Legenchuk S. F. suggests that since the institutional theory cannot be falsified (i.e. cannot be refuted), is rather a certain tool that allows to achieve certain goals by providing models of its development, than a purely accounting theory [12, p. 205]. This opinion is also held by Vysochan O. S., who postulates "the institutional approach to solving problems related to modernization of accounting, is another attempt to maintain distance from its traditional perception as means of registration of the consequences of economic events and processes by expanding the purpose, subject and method. However, the problem of its application still remains as follows: while designing on the accounting plane, it rather answers the question "Why?", but not always the question "How?" [2, p. 160].

In our view, a difference of opinions indicates that the institutional research on accounting in Ukraine is in the process of forming its paradigm, and scientists have not yet reached a final agreement on the application of the basic concepts, niche and importance of institutional theory as one of the basic foundations of the accounting.

\section{Cluster from the standpoint of institutional} theory. Today, the institutional nature of the cluster comes to the fore, as evidenced by a number of scientific papers in which it is considered as "unification, or rather new institutions of the economic system, which began to appear under the influence of institutional changes in the economy, formation new elements of the institutional environment, the development of global competition" [7, p. 122]; "a hybrid form of institutional agreement or an institution with many partially selective limited symmetric exchanges, the proportions of which are regulated by a price mechanism mediated by the creation of precautionary measures (guarantees) that minimize the risk of opportunistic behavior of economic entities and the environment" [1, p. 250]; "Market organizational and structural institution, which has a broader notion, because in addition to production and technological features it concentrates social, economic, institutional and cultural-mental parameters which give this formation a high potential for mobility, stability and high competitiveness" [4, c. 14]; "institution of development", a set of public and private structures that form horizontal and vertical economic and organizational ties that determine the rules and principles of interaction (mechanism) on the scale of these structures" [11, p. 1042].

One of the founders of institutional theory D. North states that "institutions are the rules of the game in society or, more precisely, man-made restrictions which manage human interaction in a certain direction... In real life, they take the form of legal norms, traditions, informal rules, cultural stereotypes" [16, p. 11]. 


\section{Cluster as an object of research in the institutional economy and accounting: square plates}

Accordingly, we can assume that the cluster is a modern institution that combines a system of formalized and informal relations between its members and the external environment and is characterized by certain institutional features and characteristics: ideology (increasing the competitiveness of the region, promoting economic and social development); social roles and statuses (the company-leader and the companies-members of the cluster); utilitarian features (voluntary association of enterprises, higher education institutions and local authorities); cultural symbols (brand, trademark); oral and written codes of conduct (regulations, contracts (agreement) for joint activities).

Thus, all this gives reason to consider the cluster as a modern social system and the institution of a market economy, which determines economic development and promotes competitiveness. The importance of today's clusters is determined primarily by their unique institutional environment. A cluster is a system object which is characterized by a certain set of features, properties, performed functions, which allows us to consider it righteous as an institution.

Vojnarenko M.P. notes that the cluster as an institutional category has several features unique to it, which at the same time allow to identify it as an institutional concept. The identification of these features requires consideration of the following important provisions: manifested through the interaction of human capital; realizes its potential through the use of the advantages of organizational resources; is a component of the regional innovation system [3, p. 126].

3. Institutional interaction between accounting and cluster. There is a slightly different nature of interaction between accounting as a socioeconomic institution and a cluster as a systemic institution, whereas the latter is considered in the context of the set of enterprises which create a network, and thus differs from the "common" interaction "accounting - enterprise". This form of interaction has led to the presenting and application in the scientific literature of the concept of interorganizational accounting, which is described in detail in the publications of the author $[5,6]$.

Thus, the formation and effective use of accounting information in the management system of cluster associations can be realized applying institutional approach. The main reasons which necessitate applying the concepts of institutional theory in order to solve the problems of accounting in the cluster could be reduced to the following:

1. Existence of the interdisciplinary connections. Institutionalism is a modern trend of economic theory, which takes as a basis for analysis not only economic problems, but also associates them with social, political, ethical and legal issues. Therefore, consideration of the cluster from the standpoint of institutional theory allows a comprehensive study of it from an economic, psychological, sociological, legal and other points of view. The defining features of the cluster as a socio-economic phenomenon are the presence of institutions (institute of cooperation, institute of competition and partnership, institute of communications, institute of coordination), establishing partnerships between participating companies, institutional forms of contracts (agreements), dimensional and technological distribution of the organization, informal regulations and culture.

2. Use of economic theories and concepts. After having investigated the issues of the institutional theory of accounting, Zhuk V. M. mentioned: "The lack of research into the impact of changes in the institutional environment on the formation of accounting theory, its new paradigms and concepts, gives reasons for recognized scientists to state the isolation of accounting science in their internal problems" [9, p. 141].

In our opinion, the spreading and use of the concepts of economic theory (institutionalism (T. Veblen, J. Commons, W. Mitchell); the theory of transaction costs, property rights and contract economics (R. Coase); the theory of industrial clusters (M. Porter); the theory of regional clusters (M. Enright), the theory of economic development (J. Schumpeter and others) influenced the development of accounting in the cluster by determining the substantive characteristics of the institutional accounting environment.

3. The emergence of new objects and the need for their accounting. The presence of an institutional approach is remarkable in the theory of accounting, as evidenced by the emergence of new objects (social and human capital, transaction costs, costs of innovation). These objects are not 
fully reflected in the accounting system, and therefore there is an objective need to create new approaches to their organization and methodology. In this case, institutional theory can explain the dynamics of the accounting process.

\section{Conclusions}

Thus, the study suggests that the certain concepts of accounting in the cluster were formed under the constant influence of economic theory. The application of methodological tools of institutional theory in solving accounting problems in the cluster will explain its current state and prospects for development from the standpoint of interaction of institutions. The use of institutional theory will solve the problems of theoretical and methodological nature of accounting by expanding the boundaries to the level of inter-organizational cluster management. The value of institutional theory is based on its ability to explain the current state and prospects of the accounting system from the standpoint of interaction between economic agents and individual public institutions (groups, associations), which is regulated by formal and informal norms and rules in order to improve cluster efficiency.

\section{References}

1. Bolgova, E. V. (2009). Ekonomicheskie klasteri: institutsionalnaya priroda $i$ uslovie effektivnosti innovatsionnogo karkasa regiona [Economic clusters: the institutional nature and condition for the effectiveness of the regional innovation framework]. Ekonomika i upravlenie. Ekonomicheskie nauki Economics and management. Economic sciences, (12 (61)), 249-252. [in Ukrainian]

2. Vysochan, O. S., Jakhvak, D. M. (2017). Instytutsionalizm u suchasnii vitchyznianii teorii bukhhalterskoho obliku: istorychni vytoky ta henezys [Institutionalism in contemporary domestic accounting theory: historical origins and genesis]. Prychornomorski ekonomichni studii - Black Sea Economic Studies, (16), 155-161. [in Ukrainian]

3. Vojnarenko, M. P. (2011). Klastery v instytutsiinii ekonomitsi [Clusters in the institutional economy]. $K h .: K h N U$. [in Ukrainian]

4. Gasanov, M. A., Kanov, V. I. (2013). Klaster kak strukturnyiy institut konkurentosposobnosti ekonomiki [The cluster as a structural institution of economic competitiveness]. Vestnik Tomskogo gosudarstvennogo universiteta. Ekonomika -
Bulletin of Tomsk State University. Economic, (4 (24)), 13-20. [in Ukrainian]

5. Hyk, V. V. (2019). Osoblyvosti klasteru yak orhanizatsiino-systemnoho instytutu ta yikh vplyv na pobudovu bukhhalterskoho obliku [Features of the cluster as an organizational and system institute and their influence on accounting]. Problemy teorii ta metodolohii bukhhalterskoho obliku, kontroliu $i$ analizu - Problems of theory and methodology of accounting, control and analysis, (3 (44)), 27-33. [in Ukrainian]

6. Hyk, V. V. (2018). Peredumovy formuvannia oblikovoinformatsiinoho zabezpechennia upravlinnia klasterom [Prerequisites for forming cluster management accounting information]. Problemy teorii ta metodolohii bukhhalterskoho obliku, kontroliu $i$ analizu - Problems of theory and methodology of accounting, control and analysis (2 (40)), 7-11. [in Ukrainian]

7. Evseenko, S. V., Schukin, E. Yu. (2014). Klaster kak institutsionalnoe upravlenie [The cluster as an institutional phenomenon]. Vestnik Omskogo universiteta. Seriya "Ekonomika" - Bulletin of Tomsk State University. Economic, (1), 120-123. [in Russian]

8. Zhuk, V. M. (2012). Naukova hipoteza traktuvannia bukhhalterskoho obliku yak sotsialno-ekonomichnoho instytutu [Scientific hypothesis of interpretation of accounting as a socio-economic institute]. Oblik $i$ finansy APK - Accounting and finance APK, (2), 14-22. [in Ukrainian]

9. Zhuk, V. M. (2009). Naukove oznachennia instytutsionalnoi teorii bukhhalterskoho obliku (na zasadakh idei staloho rozvytku) [Scientific definition of institutional accounting theory (based on the idea of sustainable development)]. Zbirnyk naukovykh prats Podilskoho derzhavnoho ahrarno-tekhnichnoho universytetu - Collection of scientific works of Podolsk State Agrarian Technical University, (17), tom 2, 139-146. [in Ukrainian]

10. Kancurov, O. O. (2014). Instytutsionalnyi aspekt bukhhalterskoho obliku [Institutional aspect of accounting], K.: NNC IAE, 380. [in Ukrainian]

11. Kolobova, E. A., Kolobov, A. D., Teplova, I. G., Yagolnitser, M. A. (2017). Kognitivnaya model klastera kak institutsionalnoy sistemy [Cognitive model of a cluster as an institutional system]. Kreativnaya ekonomika - Creative economy, (10), tom 11, 1039-1056. [in Russian]

12. Leghenchuk, S. F. (2010). Klasyfikatsiia teorii bukhhalterskoho obliku [Classification of accounting theories]. Problemy teorii ta metodolohii 
Cluster as an object of research in the institutional economy and accounting: square plates

bukhhalterskoho obliku, kontroliu i analizu Problems of theory and methodology of accounting, control and analysis, (3(18)), 190-211. [in Ukrainian]

13. Petruk, O. M. (2005). Harmonizatsiia natsionalnykh system bukhhalterskoho obliku [Harmonization of national accounting systems]. Zhytomyr: ZhDTU. [in Ukrainian]

14. Sljozko, T. M. (2012). Rozvytok bukhhalterskoho obliku v instytutsiinomu seredovyshchi [Development of accounting in the institutional environment]. Visnyk Kyivskoho torhovelno-ekonomichnoho universytetu - Bulletin of Kyiv University of Trade and Economics, (3), 84-93. [in Ukrainian]

15. Jukhymenko-Nazaruk, I. A. (2014). Shchodo pobudovy bukhhalterskoi instytutsiinoi kontseptsii [Concerning the construction of accounting institutional concept]. Visnyk Lvivskoi komertsiinoi akademii. Seriia: Ekonomichna - Bulletin of the
Lviv Commercial Academy, economic series, (44), 35-38. [in Ukrainian]

16. North D. (1990). Institutions, institutional change and economic performance / D. North. New York: Cambridge University Press

17. The Global Competitiveness Report 2019. Retrieved from: http://www3.weforum.org/docs/WEF_The GlobalCompetitivenessReport2019.pdf.

18. Yaremko, I. Y. (2010). Kontseptsii i paradyhmy bukhhalterskoho obliku yak systema naukovykh osnov teorii [Concepts and paradigms of accounting as a system of scientific foundations of theory]. Visnyk Natsionalnoho universytetu "Lvivska politekhnika" Menedzhment ta pidpryiemnytstvo $v$ Ukraini: etapy stanovlennia i problemy rozvytk Bulletin of the National University "Lviv Polytechnic". Management and entrepreneurship in Ukraine: stages of formation and problems of development, (691), 246-252. [in Ukrainian] 